\title{
Francisco Gómez Martos, La creación de una historia nacional. Juan de Mariana y el papel de la Antigüedad en la Edad Moderna. Madrid: Dykinson, 2018, 272 págs.
}

Los estudios sobre historiografía española parecen contar con buena salud y se encuentran aportes crecientes en muy diferentes campos. ¿Es solo una percepción personal que, con todo, sigue siendo un mundo con desigualdades notables en los diferentes períodos?

Mi impresión, dicho sea sin ningún tipo de triunfalismo, es que contamos con una situación razonablemente buena para las historias Antigua y Contemporánea, y quizá en un nivel similar para Prehistoria, aunque el mundo de la historia contemporánea, por razones obvias, sea también, por una parte, el que tenga más tareas por delante y, por otra, el que más ha hecho por aportar aspectos tan cruciales como los estudios sobre institucionalización de nuestro saber en el XIX y en el XX. En lo tocante a la historiografía Medieval y Moderna, quedaría, si tengo razón, mucho más por hacer. Quizá bastaría con tener presente para la segunda los índices de la Historia de la Historiografía Española de Benito Sánchez Alonso y contrastarlos con los estudios presentes y, más en particular, con la falta de un libro equivalente después de más de medio siglo. Yo diría que quedan por tratar buena parte de los grandes, por no hablar de los pequeños, historiadores, géneros enteros como las historias locales, estudios de problemas específicos y tantas otras cosas...

Que el libro de Francisco Gómez Martos represente una novedad en tanto que se refiere al Padre Mariana es otra señal clara. Que para estudiar al que es muy probablemente el historiador más trascendente de la historia de España hasta el siglo XIX haya que recurrir, dejando aparte, sobre todo, artículos, buena parte de ellos meritorios, y mucho, a la vieja monografía de Cirot de comienzos del XX, es significativo en el mismo sentido.

El libro de Gómez Martos se plantea explorar al Padre Mariana desde la perspectiva de su enfoque de la Antigüedad. Su estructura es consistente con ello: una segunda parte dedicada a los diferentes momentos de la Antigüedad desde los tiempos primitivos hasta el final del Imperio Romano, y una primera en la que se introduce brevemente el estado de la historiografía en el XVI en España y la vida y obra de Mariana. Y siguen unas conclusiones sobre fuentes, perspectivas del proyecto y resultados.

El libro de Gómez Martos es un libro medido, bien construido y bien razonado, que nos presenta a un Mariana poco original en el estudio de las fuentes, más recopilador que creador, que debe mucho, por tanto, a sus predecesores, que cumple el papel que se propone, que es crucial a la hora de generar un estilo de prosa histórica a la altura de los tiempos, que no se arriesga frente a falsarios, pero que tampoco se resigna a no dejar claros sus intereses y preocupaciones.

Así, si la Antigüedad ofrecía en las fuentes que legaba materiales para poner las bases de una identidad colectiva, por supuesto prerromana, que continuaría hasta el 
presente, ofrecía también ocasiones para la reflexión desde la propia riqueza del pensamiento antiguo, presidida por la continuidad de la memoria histórica desde el siglo $\mathrm{V}$ a. C. en adelante. El propio hecho de que los antepasados hubieran acabado bajo el peso de la "dominación romana" e incluso la renovación de sus esencias con su final, llamaba a participar de la inquietud intelectual de las fuentes grecorromanas alrededor del problema de la duración de los imperios.

La vieja preocupación por el imperio romano que tan bien concretaba, de Cicerón a Macrobio, el viejo tema del Sueño de Escipión, se re-actualiza en Mariana en clave cristiana, moralista $\mathrm{y}$, por supuesto, patriótica, sin perder las cargas emocionales originales ligadas al peligro de la destrucción del grupo al que se pertenece. En este sentido, llama la atención su falta de triunfalismo y de optimismo sobre el propio imperio español, que apunta incluso a dudas sobre su conveniencia, lo que quizás sea más crucial a la hora de marcar las imágenes colectivas de lo español en el futuro de lo que parece. En el fondo quizás dejaba el campo bien abonado para las futuras imágenes trágicas de la identidad española que culminaron en la orgía masoquista del 98.

El libro de Gómez Martos, en síntesis, significa un importante paso adelante. Pone las bases también de la necesidad de estudios equivalentes sobre Mariana desde el tratamiento de los visigodos en adelante y llama a dejar atrás el fraccionamiento de los estudios parciales y a intentar visiones más ambiciosas.

También llama, como mínimo, a dos reflexiones, las dos requiriendo miradas que desborden la Península Ibérica. Afortunadamente, la historiografía española cuenta cada vez más con estudiosos, empezando por el propio Gómez Martos, que han sabido salir de las limitaciones del exclusivismo de los estudios hispanos. La primera, hay que admitirlo, no es nada original: se trata de la propia reflexión sobre el uso del concepto "nacionalismo" para sociedades preindustriales. Es una reflexión que obliga a depurar conceptos, entre ellos los ligados a pertenencia, identidad colectiva, el papel del Estado y sus ingenierías, "soberanía popular" y otros, y que está muy lejos de estar resuelta. La existencia de identidades colectivas -yo proponía hace años el concepto de "relaciones de pertenencia"- es universal, pero cabría plantearse si, y de qué manera, estructuras políticas y sociales distintas nos obligan o no a generar terminologías diferenciadas.

La segunda es más crucial, y se trata de la necesidad de estudiar a los historiadores y las historiografías europeas globalmente. Si en el contexto del Estado Moderno en toda Europa se construyen historias como la de Mariana, el arte representa a los pretendidos antepasados o el teatro los pone en escena -a la manera de Cervantes en la Numancia- y temas y personajes circulan en y entre estos vehículos culturales, el fenómeno llama a una reflexión global: no entenderemos a Mariana sin entenderlo como fenómeno europeo, y no entenderemos la historiografía europea y la multiplicidad de sus funciones en ese nuevo marco sin entender a todos sus Marianas.

Fernando Wulff Alonso

Universidad de Málaga

wulff@uma.es 
Fecha de recepción: 31 de julio de 2018.

Fecha de aceptación: 6 de septiembre de 2018.

Publicación: 31 de diciembre de 2018.

Para citar este artículo: Fernando Wulff Alonso, "Francisco Gómez Martos, La creación de una historia nacional. Juan de Mariana y el papel de la Antigüedad en la Edad Moderna. Madrid: Dykinson, 2018, 272 págs.", Historiografías, 16 (julio-diciembre, 2018): 148-150. 